\title{
ESTIMATION OF LIVE WEIGHT OF HOLSTEIN-FRIESIAN BULLS BY USING BODY LINEAR MEASUREMENTS
}

\author{
TUTKUN, M. \\ Department of Animal Science, Faculty of Agricultural, Dicle University \\ 21280 Diyarbakır, Turkey \\ (e-mail: tutkunmuhittin@yahoo.com; phone: +90-412-241-1000; fax: +90-412-241-1048) \\ (Received $5^{\text {th }}$ Nov 2018; accepted 28 $8^{\text {th }}$ Jan 2019)
}

\begin{abstract}
The objective of this study was to estimate the body weight of Holstein-Friesian cattle by using multiple regression analysis. Data were collected from 29 Holstein-Friesian bulls, whose live weight, body length (BL), height at withers, chest depth, heart girth (HG), shin circumference (SC), rump height, and back rump height were measured. There was a relationship between dependent and independent variables. The estimated multiple regression equation was $-431.8+2.438 \mathrm{HG}+21.21 \mathrm{SC}+1.041 \mathrm{BL}$, with a determination coefficient of 0.9987 and a standard error of the estimate of 5.240.
\end{abstract}

Keywords: body weight, Holstein, heart girth, measurement, regression analysis

\section{Introduction}

Estimating the live body weight of animals through body measurements is a practical, faster, easier, and cheaper method in rural areas where resources are scarce (Nsoso et al., 2003). Knowing the animal live weight is important for breeders, since this information allows them to estimate market prices for live animals and to determine the right dosages in drug administration and the amount of feed to be supplied for growth, maintenance, and production (Mahieu et al., 2011; Chitra et al., 2012; Tsegaye et al., 2013).

Body measurements have been widely used for estimating live weight. There is a relationship between live weight and the various body lengths, heights, and girths measured on live animals.

Using body measurements to estimate live weight with a simple measuring stick and tape may provide relative accuracy and consistency.

Live weight forms the basis for a range of research and management activities including assessment of growth rates, animal responses to different diets and environmental conditions, and determination of feed requirements. Knowing the animal weight and weight changes is also important in determining responses to genetic selection (Touchberry and Lush, 1950).

The use of linear body measurements in fattening beef cattle carries some advantages over subjective methods of cattle evaluation that involve visual assessment and scoring (Essien and Adesope, 2003). Some authors have also suggested this approach to be more reliable than weight measured with a weighing scale, since the latter can be subject to short-term effects such as gut fill, urination, and defecation (Russell, 1975).

These measurements can be taken at lower costs (when labor costs are relatively low) with a simple measuring tape and may provide relative accuracy and consistency (Guilbert and Gregory, 1952)

This is not only a sign of adult weight of the breed but also important for prediction of the daily weight gain and making the feeding programs (Tüzemen and Yanar, 2013). 
There are several methods to estimate live weight in cattle. The polynomial regression was used to predict live weight in cattle (Assogba et al., 2017). Body weight and wither height were regressed on the other body traits. Regressions of body weight including the linear, quadratic, and cubic effects of a single independent variable (heart girth, wither height, hip width or body length) indicated that each measurement would be useful in predicting body weight (Heinrichs et al., 1992)

Digital Image Analysis was used in order to predict of body weight and carcass performance of beef cattle as well (Bozkurt et al., 2008)

However, the linear body measurements are used mostly to predict live weight in cattle and small ruminants. It is based on the measurement of heart girth, which is reported to be highly correlated with body weight in cattle (Heinrichs, 2007; Swali et al., 2008).

The objective of this study was to develop the best prediction models to estimate body weight based on linear body measurements.

\section{Materials and methods}

The experiment was conducted in Dicle University, Cattle Research Center in Diyarbakir Province, Turkey (37 $57^{\prime} 41 \mathrm{~N}$ and $40^{\circ} 13^{\prime} 54 \mathrm{E}, 650 \mathrm{~m}$ asl).

The study material consisted of monthly live weight and body measurement records of 29 male Holstein-Friesian bulls collected between the years 2016 and 2017. The initial weight was taken at age of 4 month. Different amounts of concentrate and roughage were provided ad libitum to the bulls considering the average live weights obtained from the monthly weighings.

A measuring stick was used to determine body length (BL), height at withers (HAW), chest depth (CD), rump height (RH), and back rump height (BRH), whereas a tape measure was used to determine heart girth $(\mathrm{HG})$ and shin circumference (SC). Body measurements were taken once monthly with the bulls standing in a squeeze chute. Bulls were weighed before feeding and drinking water in the early morning.

The animals were weighed monthly using an electronic weighing scale with $1,500-\mathrm{kg}$ capacity. Body measurements were taken by same observers so as to minimize bias. All the data were recorded in centimeters.

Descriptive statistics was used to present the simple means and standard deviation for all variables. Regressions of live weight (LW) on $\mathrm{HG}, \mathrm{CD}, \mathrm{RH}, \mathrm{HAW}, \mathrm{SC}, \mathrm{BRH}$, and $\mathrm{BL}$ were performed using simple and multiple linear regressions with the various body measurements as continuous variables. The obtained data were analyzed using Minitab 18 statistical software (Pearson's correlation coefficients), where correlations between body weight and different body measurements were computed.

Regression analysis was employed to predict live weight from different body measurements. The best-fitting regression model was chosen based on the coefficient of determination $\left(\mathrm{R}^{2}\right)$ and standard deviation (SD). Multiple regression models were followed to estimate body weight from body measurements.

The Stepwise regression model of the measurements (all seven linear body measurements) was defined as follows (Eq. 1):

$$
Y=\beta_{0}+b_{1} \beta_{1}+\beta_{2} X_{2}+\beta_{3} X_{3}+\beta_{4} X_{4}+\beta_{5} X_{5}+\beta_{6} X_{6}+\beta_{7} X_{7}+e_{i}
$$

in which: 
$\mathrm{Y}=$ dependent variable (live weight),

$\beta \mathrm{o}=$ intercept,

$\beta^{`} \mathrm{~s}=$ regression coefficients,

$\mathrm{X}_{(1 \text { to 7) }}=$ independent variables (HG, $\mathrm{CD}, \mathrm{RH}, \mathrm{HAW}, \mathrm{SC}, \mathrm{BRH}$, and $\left.\mathrm{BL}\right)$ and $\mathrm{e}_{\mathrm{i}}=$ error.

\section{Results}

In the statistical analyses, the mean and standard deviations were calculated for each attribute (Table 1).

Table 1. Descriptive statistics of live weight and body measurements

\begin{tabular}{c|c|c|c|c|c}
\hline $\begin{array}{c}\text { Fattening } \\
\text { period }\end{array}$ & $\mathbf{N}$ & $\begin{array}{c}\text { Live weight } \\
\text { Mean } \pm \text { SD }\end{array}$ & $\begin{array}{c}\text { Height at withers } \\
\text { Mean } \pm \text { SD }\end{array}$ & $\begin{array}{c}\text { Rump height } \\
\text { Mean } \pm \text { SD }\end{array}$ & $\begin{array}{c}\text { Chest depth } \\
\text { Mean } \pm \text { SD }\end{array}$ \\
\hline Initial & 29 & $99.90 \pm 16.03$ & $94.03 \pm 4.52$ & $99.03 \pm 4.52$ & $35.82 \pm 2.36$ \\
30 days & 29 & $135.16 \pm 17.48$ & $97.93 \pm 4.69$ & $102.93 \pm 4.83$ & $38.55 \pm 2.55$ \\
60 days & 29 & $170.99 \pm 18.87$ & $102.03 \pm 4.66$ & $106.79 \pm 4.89$ & $39.03 \pm 2.38$ \\
90 days & 29 & $207.52 \pm 20.05$ & $108.03 \pm 4.00$ & $110.79 \pm 4.89$ & $41.32 \pm 2.85$ \\
120 days & 29 & $244.42 \pm 21.94$ & $112.76 \pm 4.06$ & $116.03 \pm 4.33$ & $44.55 \pm 3.51$ \\
150 days & 29 & $281.38 \pm 23.33$ & $116.76 \pm 4.07$ & $120.17 \pm 4.28$ & $54.18 \pm 3.61$ \\
180 days & 29 & $317.16 \pm 24.58$ & $118.45 \pm 4.05$ & $124.10 \pm 4.12$ & $56.66 \pm 3.77$ \\
210 days & 29 & $355.52 \pm 29.62$ & $120.41 \pm 4.06$ & $127.72 \pm 4.02$ & $57.44 \pm 3.55$ \\
240 days & 29 & $394.24 \pm 31.48$ & $121.28 \pm 3.97$ & $129.55 \pm 3.95$ & $58.27 \pm 3.25$ \\
270 days & 29 & $432.86 \pm 32.14$ & $123.24 \pm 3.99$ & $131.03 \pm 4.01$ & $60.65 \pm 3.19$ \\
300 days & 29 & $471.72 \pm 35.91$ & $125.21 \pm 3.99$ & $131.86 \pm 3.96$ & $61.18 \pm 2.72$ \\
330 days & 29 & $516.38 \pm 39.03$ & $126.21 \pm 3.98$ & $132.72 \pm 4.03$ & $62.55 \pm 2.83$ \\
Final & 29 & $553.66 \pm 34.48$ & $127.31 \pm 4.36$ & $133.52 \pm 4.09$ & $64.18 \pm 3.18$ \\
\hline
\end{tabular}

Table 1. (cont.) Descriptive statistics of live weight and body measurements

\begin{tabular}{c|c|c|c|c|c}
\hline $\begin{array}{c}\text { Fattening } \\
\text { period }\end{array}$ & $\mathbf{N}$ & $\begin{array}{c}\text { Heart girth } \\
\text { Mean } \pm \text { SD }\end{array}$ & $\begin{array}{c}\text { Shin } \\
\text { circumference } \\
\text { Mean } \pm \text { SD }\end{array}$ & $\begin{array}{c}\text { Body length } \\
\text { Mean } \pm \text { SD }\end{array}$ & $\begin{array}{c}\text { Back rump height } \\
\text { Mean } \pm \text { SD }\end{array}$ \\
\hline Initial & 29 & $95.21 \pm 6.78$ & $10.24 \pm 1.02$ & $81.13 \pm 3.92$ & $111.55 \pm 3.94$ \\
30 days & 29 & $102.38 \pm 6.56$ & $10.65 \pm 0.81$ & $88.20 \pm 3.85$ & $114.69 \pm 4.31$ \\
60 days & 29 & $106.79 \pm 4.89$ & $10.72 \pm 0.84$ & $94.13 \pm 3.92$ & $118.14 \pm 4.21$ \\
90 days & 29 & $118.55 \pm 5.64$ & $11.55 \pm 1.05$ & $100.17 \pm 3.01$ & $123.28 \pm 4.36$ \\
120 days & 29 & $131.17 \pm 6.48$ & $11.79 \pm 1.14$ & $106.38 \pm 2.78$ & $128.14 \pm 4.36$ \\
150 days & 29 & $137.59 \pm 6.01$ & $12.10 \pm 1.17$ & $112.83 \pm 2.36$ & $132.93 \pm 4.33$ \\
180 days & 29 & $150.55 \pm 6.21$ & $12.37 \pm 1.14$ & $119.55 \pm 4.88$ & $136.72 \pm 4.06$ \\
210 days & 29 & $156.48 \pm 6.17$ & $12.62 \pm 1.26$ & $131.72 \pm 2.85$ & $138.66 \pm 4.40$ \\
240 days & 29 & $157.55 \pm 6.23$ & $14.55 \pm 1.27$ & $132.69 \pm 2.73$ & $140.34 \pm 6.63$ \\
270 days & 29 & $171.93 \pm 6.26$ & $14.55 \pm 1.21$ & $134.31 \pm 2.69$ & $142.21 \pm 8.33$ \\
300 days & 29 & $174.07 \pm 5.85$ & $15.51 \pm 1.18$ & $135.72 \pm 2.75$ & $144.07 \pm 6.00$ \\
330 days & 29 & $176.55 \pm 5.77$ & $17.44 \pm 1.37$ & $137.59 \pm 2.58$ & $146.17 \pm 6.97$ \\
Final & 29 & $182.83 \pm 5.93$ & $18.82 \pm 1.97$ & $139.21 \pm 2.83$ & $148.52 \pm 4.31$ \\
\hline
\end{tabular}


All correlation coefficients were positive and highly significant $(\mathrm{P}<0.01)$, and the highest correlation coefficient was determined between BW and heart girth (Table 2).

Table 2. The correlation coefficients between dependent and independent variables

\begin{tabular}{c|c|c|c|c|c|c|c|c}
\hline & BW & HAW & RH & CD & HG & SR & BL & BRH \\
\hline BW & 1 & - & - & - & - & - & - & - \\
\hline HAW & $0.956 * *$ & 1 & - & - & - & - & - & - \\
\hline RH & $0.964 * *$ & $0.993 * *$ & 1 & - & - & - & - & - \\
\hline CD & $0.956 * *$ & $0.987 * *$ & $0.992 * *$ & 1 & - & - & - & - \\
\hline HG & $0.987 * *$ & $0.981 * *$ & $0.989 * *$ & $0.982 * *$ & 1 & - & - & - \\
\hline SR & $0.968^{* *}$ & $0.848 * *$ & $0.854 * *$ & $0.848^{* *}$ & $0.903 * *$ & 1 & - & - \\
\hline BL & $0.978^{* *}$ & $0.982 * *$ & $0.996 * *$ & $0.983 * *$ & $0.988^{* *}$ & $0.864 * *$ & 1 & - \\
\hline BRH & $0.966 * *$ & $0.994 * *$ & $0.996 * *$ & $0.992 * *$ & $0.993 * *$ & $0.885 * *$ & $0.990 * *$ & 1 \\
\hline
\end{tabular}

P-value $<0.01$

All possible regression equations were employed in the selection of a best fitted regression equation as represented in Table 2. The results showed that the multiple regression equation for estimation of body weight of Holstein-Friesian bulls had tree independent variables, $\mathrm{x}_{1}$ (heart girths), $\mathrm{x}_{2}$ (shin circumference) and $\mathrm{x}_{3}$ (body length) with high adjusted coefficients of determination $\left(\mathrm{R}^{2}=99.87\right)$ and low standard error of estimation $(\mathrm{S}=5.240)$ in equation $\left(\mathrm{Y}_{3} ; E q .2\right)$.

$$
Y_{3}=-431.8+2.438 \mathrm{HG}+21.21 \mathrm{SC}+1.041 \mathrm{BL}
$$

$\mathrm{R}^{2}$ was calculated as 0.973 by using multiple linear regression analysis based on the HG to design a body-weight prediction model. When SC was added to regression model $\mathrm{R}^{2}$ value was found as 0.9986 . The best-fitting model, with the highest $\mathrm{R}^{2}$ value (0.9987), was obtained by adding BL to the equation (Table 3).

Table 3. The regression equation for live weights of Holstein bulls

\begin{tabular}{c|c|c|c}
\hline & $\mathbf{1}$ & $\mathbf{2}$ & $\mathbf{3}$ \\
\hline Coef & $\mathbf{- 3 7 8 . 3}$ & $\mathbf{- 4 1 0 . 4 5 7}$ & $\mathbf{- 4 3 1 . 8}$ \\
HG & 4.876 & 3.247 & 2.438 \\
T-Value & 20.25 & 24.20 & 5.760 \\
P-Value & .000 & .000 & .000 \\
SR & - & 20.0 & 21.21 \\
T-Value & - & -13.46 & 14.73 \\
P-Value & - & .000 & .000 \\
BL & - & - & 1.041 \\
T-Value & - & - & 1.99 \\
P-Value & 24.865 & 5.965 & .012 \\
S & 0.9739 & 99.86 & 5.240 \\
$R^{2}$ & $Y_{1}=-378.3+4.876 H G\left(R^{2}=0.9739\right)$ \\
\multicolumn{4}{c}{$Y_{2}=-410.457+3.247 H G+20 S R\left(R^{2}=0.9986\right)$} \\
\hline \multicolumn{3}{c}{}
\end{tabular}


Live weight and linear body measurements were significantly correlated with each other. Body weight had a higher correlation with HG than with any other body measurements (CD, RH, HAW, SC, BRH, and BL). In all fattening periods evaluated, the highest $\mathrm{R}^{2}$ was obtained when the $\mathrm{SC}$ and $\mathrm{BL}$ measurements were included in the regression equations, which suggests that body weight could be more precisely estimated by the association of two or more linear measurements. However, the association of different body measurements (body length and shin circumference) would produce the best prediction equation for body weight, in this study.

The coefficients of correlation between heart girth and body weight were 0.973 for all of the 29 Holstein-Friesian bulls, and highly statistically significant. The relationship between live weight and heart girth was illustrated by graph shown as Figure 1.

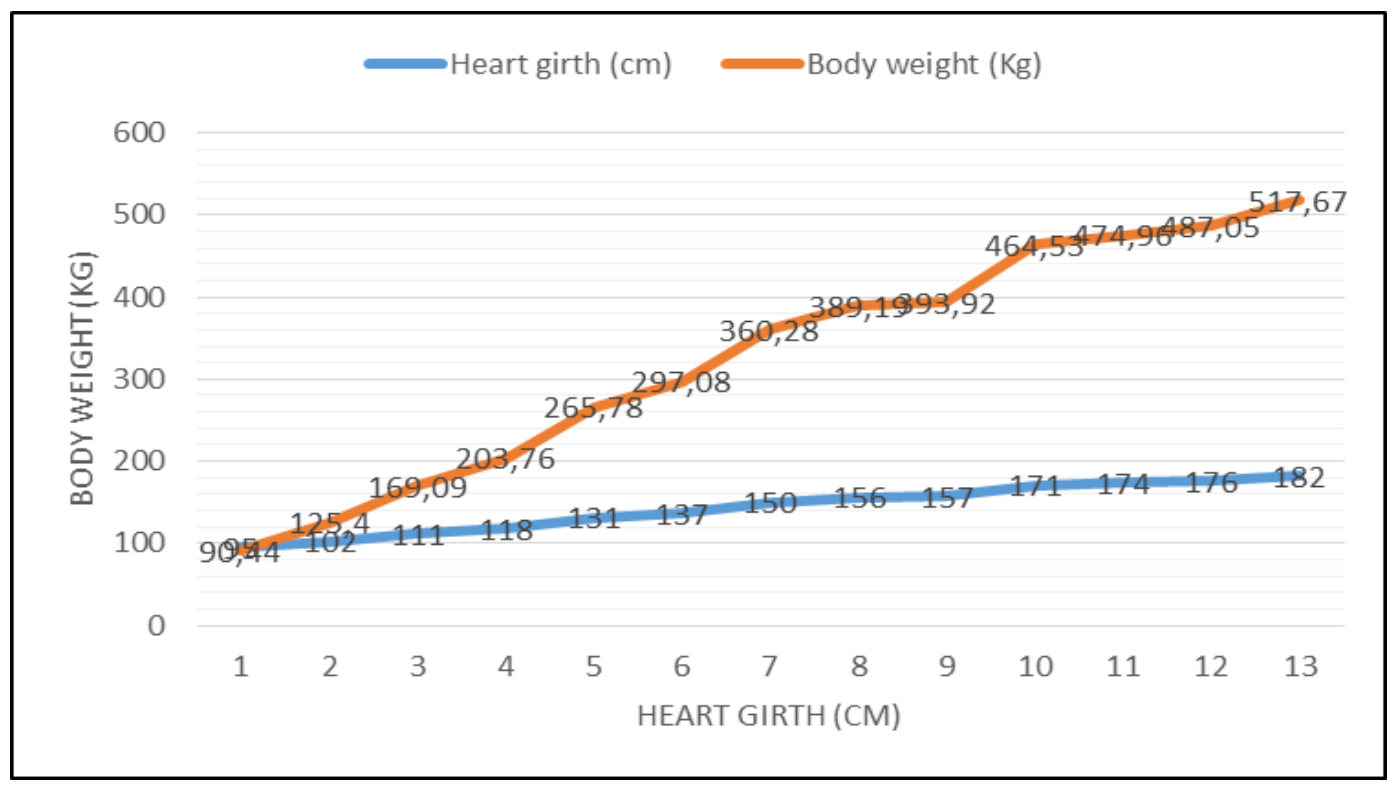

Figure 1. Relationship between live weight and heart girth

The regression of body weight on heart girth indicated a straight-line relationship.

The body weight of Holstein- Friesian cattle were estimated by using the multiple regression equation between the live weight and heart girth $\left(\mathrm{Y}_{1}\right)$ represented in Table 4 and the comparison between the real values and the predicted values of body weight of Holstein-Friesian cattle was shown in Table 5.

Table 4. Prediction of body weight of Holstein-Friesian cattle based on heart girth

\begin{tabular}{c|c|c|c}
\hline $\begin{array}{c}\text { Heart girth } \\
(\mathbf{c m})\end{array}$ & $\begin{array}{c}\text { Predicted body weight } \\
(\mathbf{k g})\end{array}$ & $\begin{array}{c}\text { Heart girth } \\
(\mathbf{c m})\end{array}$ & $\begin{array}{c}\text { Predicted body weight } \\
(\mathbf{k g})\end{array}$ \\
\hline 95 & 90.44 & 156 & 389.19 \\
102 & 125.40 & 157 & 393.92 \\
111 & 169.09 & 171 & 464.53 \\
118 & 203.76 & 174 & 474.96 \\
131 & 265.78 & 176 & 487.05 \\
137 & 297.08 & 182 & 517.67 \\
150 & 360.28 & & \\
\hline
\end{tabular}


Table 5. Actual and predicted body weight

\begin{tabular}{c|c|c}
\hline Heart girth $(\mathbf{c m})$ & Actual body weight $\mathbf{( k g )}$ & Predicted body weight $\mathbf{( k g )}$ \\
\hline 95 & 99.9 & 90.44 \\
102 & 135.16 & 125.4 \\
111 & 170.99 & 169.09 \\
118 & 207.52 & 203.76 \\
131 & 244.42 & 265.78 \\
137 & 281.38 & 297.08 \\
150 & 317.16 & 360.28 \\
156 & 355.52 & 389.19 \\
157 & 394.24 & 393.92 \\
171 & 432.86 & 464.53 \\
174 & 471.72 & 474.96 \\
176 & 516.38 & 487.05 \\
182 & 553.66 & 517.67 \\
\hline
\end{tabular}

Actual and predicted body weight of Holstein-Friesian bulls were illustrated by graph shown as Figure 2.

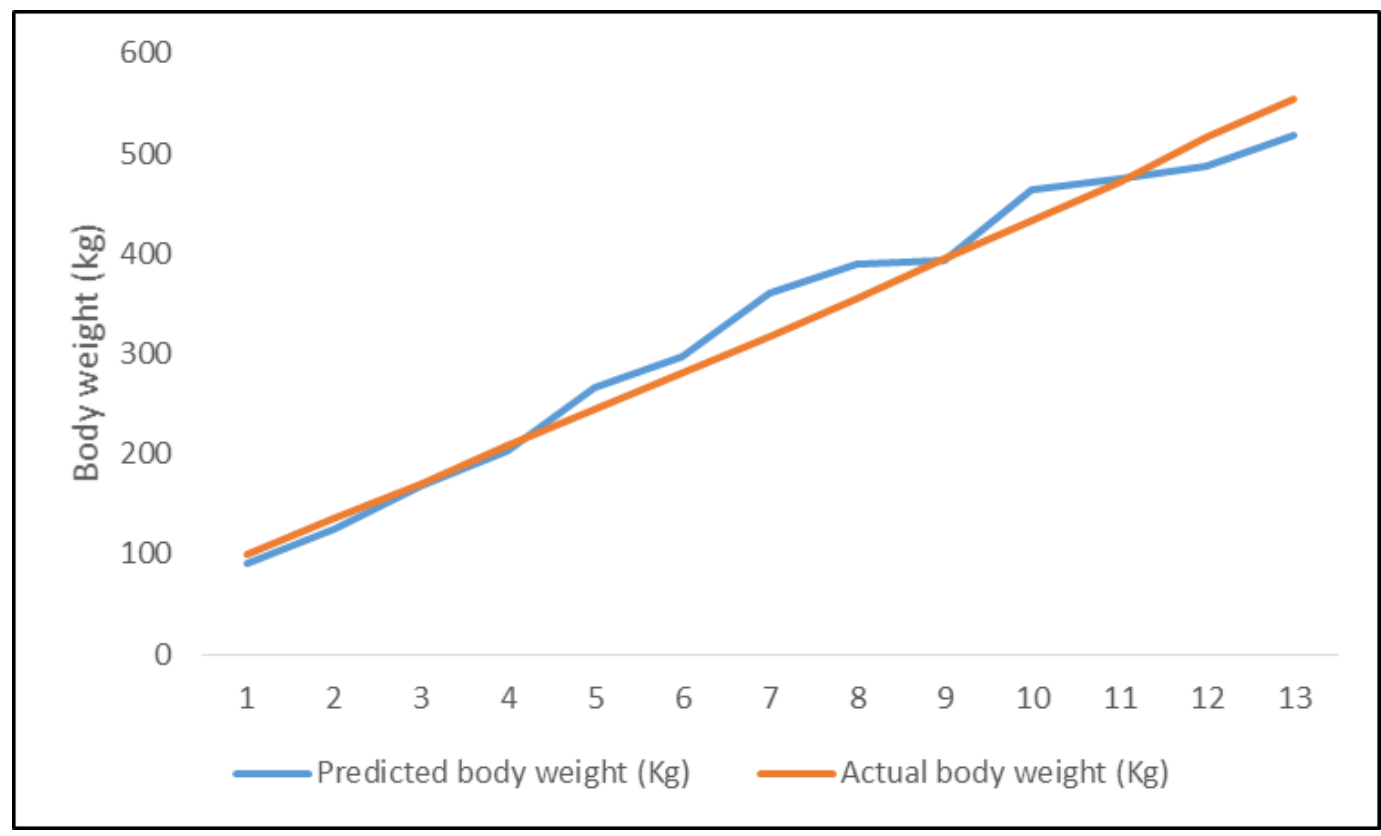

Figure 2. Actual and predicted live weight values of Holstein bulls

\section{Discussion}

The present findings corroborate Katongole et al. (2013), according to whom HG, $\mathrm{WH}$, and body condition score (BCS) were the variables with the highest $\mathrm{R}^{2}$ value for predicting body weight. Siddiqui et al. (2015) reported that the HG and BL were the best variables for this purpose, with $\mathrm{R}^{2}=0.968$. Our results also agree with those published by Yan et al. (2009), who found that HG, BL, and BCS were better suited parameters for estimating body weight. 
The highest correlation obtained in this study was between LW and HG measurement while the lowest was with $\mathrm{CD}$. The high correlation between LW and HG can be attributed to the fact that, in comparison to length and HW, HG more closely reflects body condition of cows (Goe et al., 2001). This fact may also be supported by the stronger correlation observed in the present study between HG, LW and body condition scores compared to BL. Such correlations have also been reported by other workers (Francis et al., 2002; Gunawan and Jakaria, 2010; Heinrichs et al., 1992, 2007; Kashoma et al., 2011; Msangi et al., 1999; Yan et al., 2009; Lukuyu et al.2016).

The relationship between body linear measurements and LW could be exploited in designing appropriate management and selection programs in that high positive relationships among the traits suggests that an increase in one could lead to a corresponding increase in the other trait (Assan, 2013).

Body weight was highly correlated with heart girth in cattle, as concluded by Abdelhadi and Babiker (2009), Bagui and Valdez (2007) and Nesamvuni et al. (2000).

The current results are similar to those reported by Soysal and Konak (1992), Tüzemen et al. (1995), Yanar et al. (1995), Mantysaari (1996), Seokgeum et al. (1998), Adeyinka and Mohammed (2006), Koç and Akman (2007), Sawanon et al. (2011) and Mekparyup et al. (2013).

\section{Conclusions}

The high values coefficients of correlation $\left(\mathrm{R}^{2}\right)$ of the equation obtained by multiple regression analysis suggest that heart girth can be practically used alone to estimate live weight. Regression coefficients for heart girth indicate that such estimators could be used independently to estimate body weight in Holstein-Friesian bulls. Estimating the body weight of Holstein-Friesian cattle using three independent variables heart girth, shin circumference and body length appears to be a useful strategy. Linear body measurements, specifically heart girth, are useful predictors of live weight in cattle. Heart girth is the most practical parameter for predicting live weight in field conditions, especially for smallholder farmers.

\section{REFERENCES}

[1] Abdelhadi, O. M. A., Babiker, S. A. (2009): Prediction of Zebu Cattle Live weight using live animal measurements. - Livestock Research for Rural Development 21: 133.

[2] Adeyinka, A. A., Mohammed, I. D. (2006): Accuracy of body weight prediction equation in Nigerian Red Sokoto goats raised in North Eastern Nigeria using linear body measurements. - Pak. J. Biol. Sci. 9(15): 2828-2830.

[3] Assan, N. (2013): Bioprediction of body weight and carcass parameters from morphometric measurements in livestock and poultry. - Sci J Rev. 2: 140-150.

[4] Assogba, B. G. C., Adjassin, J. S., Alkoiret, T. I. (2017): Use of body measurements to estimate live weight of Lagune cattle in Southern Benin. - Saudi J. Life Sci 2(2): 23-32.

[5] Bagui, N. J. G., Valdez, C. A. (2007): Live weight estimation of locally raised adult purebred Brahman cattle using external body measurements. - Philippines Journal of Veterinary Medicine 44: 36-42.

[6] Chitra, R., Rajendran, S., Prasanna, D., Kirubakaran, A. (2012): Prediction of body weight using appropriate regression model in adult female Malabari goat. - Vet World 5(7): 409-411.

[7] Ensminger, M. E. (1991): The Stockman's Handbook. 7th ed. - Prentice Hall, USA. 
[8] Essien, A., Adesope, O. M. (2003): Linear Body Measurements of N'dama Calves at 12 Months in a South Western zone of Nigeria. - Livest Res Rural Dev 15(4): 34.

[9] Francis, J., Sibanda, S., Kristensen, T. (2002): Estimating body weight of cattle using linear body measurements. - Zimb Vet J. 33: 15-21.

[10] Goe, M. R., Alldredge, J. R., Light, D. (2001): Use of heart girth to predict body weight of working oxen in the Ethiopian highlands. - Livest Prod Sci. 69: 187-195. doi: 10.1016/S0301-6226(00)00257-8.

[11] Guilbert, H. R., Gregory, P. W. (1952): Some features of growth and development of Hereford cattle. - Journal of Animal Science 11: 3-16.

[12] Gunawan, A., Jakaria, J. (2010): Application of linear body measurements for predicting weaning and yearling weight of bali cattle. - Anim Prod. 12: 163-168.

[13] Heinrichs, A. J., Rogers, G. W.,Cooper, J. B. (1992): Predicting Body Weight and Wither Height in Holstein Heifers Using Body Measurements. - J. Dairy Sci. 75(12): 3576-3581.

[14] Heinrichs, A. J., Erb, H. N., Rodgers, G. W., Cooper, J.B, Jones, C. M. (2007): Variability in Holstein heifer heart-girth measurements and comparison of prediction equations for live weight. - Prev Vet Med. 78: 333-338. DOI: 10.1016/j.prevetmed.2006.11.002.

[15] Kashoma, I. P. B., Luziga, C., Werema, C. W., Shirima, G. A., Ndossi, D. (2011): Predicting body weight of Tanzania shorthorn zebu cattle using heart girth measurements. - Livst Res Rural Dev 23: 94.

[16] Katongole, C. B., Mpairwe, D.,Bareeba, F. B., Mukasa-Mugerwa, E., Ebong, C. (2013): Predicting body weight from heart girth, height at withers and body condition score in Bos İndicus cattle bulls of Uganda. - Livestock Research for Rural Development 25(3).

[17] Koç, A., Akman, N. (2007): Siyah-Alaca Tosunların Değişik Dönemlerdeki Vücut Ölçüleri ve Vücut Ölçülerinden Canlı ağırlığın Tahmini. - ADÜ Ziraat Fak. Dergisi 4(12): 21-25.

[18] Lukuyu, M.N, Gibson, J. P., Savage, D. B., Duncan, A. J., Mujibi, F. D., Okeyo, A. M. (2016): Use of body linear measurements to estimate live weight of crossbred dairy cattle in smallholder farms in Kenya. - Springer Plus 5: 63. DOI: [10.1186/s40064-016-16983].

[19] Mahieu, M., Naves, M., Arquet, R. (2011): Predicting the body mass of goats from body measurements. - Livestock Research for Rural Development 23: 192.

[20] Mantysaari, P. (1996): Predicting body weight from body measurements of pre-pubertal Ayrshire heifers. - Agric. Sci. Finland. 5: 17-23.

[21] Mekparyup, J., Saithanu, K., Arunkeeree, N. (2013): Estimation of body weight of Holstein-Friesian cattle with multiple regression analysis. - International Journal of Applied Mathematics and Statistics 44(14): 1-7.

[22] Msangi, B. S. J., Bryant ,M. J., Kavana, Y., Msanga, N., Kizima, J. B. (1999): Body measurements as a management tool for crossbred dairy cattle at a smallholder farm condition. - In: Mbaga, S. H. (ed.) Proceedings of 26th scientific conference of Tanzania Society of Animal Production, $3^{\text {rd }}$-5th August. LITI, Tengeru, Arusha, Tanzania.

[23] Nesamvuni, A. E., Mulaudzi, J., Ramanyimi, N. D., Taylor, G. J. (2000): Estimation of body weight in Nguni-type cattle under communal management conditions. - South African Journal of Animal Science 30(Suppl. 1): 97-98.

[24] Nsoso, S. J., Aganga, A. A., Moganetsi, B. P., Tshwenyane, S. O. (2003): Body weight, body condition score and heart girth of goats during the dry and wet seasons in Southeast Bostwana. - Livest. Res. Rural Develop. 15(4).

[25] Russell, W. S. (1975): The growth of Ayrshire cattle: an analysis of linear body measurements. - Animal Production 21: 217-226.

[26] Sawanon, S. Boonsaen, P., Innuruk, P. (2011): Body measurements of male Kamphaengsaen beef cattle as parameters for estimation of live weight. - Kasetsart J. (Nat. Sci.). 45: 428-434. 
[27] Seokgeum, J., Hyeongseon, K., Jongmoon, L., Yunbae, J., Jeongdae, H. (1998): Study on the prediction of body weight in Holstein dairy cattle using body measurements. - RDA J. Livestock Sci. 40: 126-129.

[28] Siddiqui, M. U., Lateef, M., Bashir, K.L, Bilal, M. Q., Muhammad, G., Mustafa, M. I., Rehman, S. (2015): Estimation of live weight using different body measurements in Sahiwal cattle. - Pakistan Journal of Life Social Science 13(1): 12-15.

[29] Soysal, I., Konak, F. (1992): Sığırlarda çeşitli Vücut Ölçümleri ile Canlı Ağırlık ve Karkas Ağırlıkları İlişkileri Üzerine Araştırmalar. - T. Ü. Tekirdağ Ziraat Fak. Dergisi 1: 187-200.

[30] Touchberry, R. W., Lush, J. L. (1950): The accuracy of linear body measurements of dairy cattle. - J Dairy Sci. 33: 72-80.

[31] Swali, A., Cheng, Z., Bourne, N., Wathes, D. C. (2008): Metabolic traits affecting growth rates of pre-pubertal calves and their relationship with subsequent survival. - Domest Anim Endocrinol 35: 300-313. DOI: 10.1016/j.domaniend.2008.06.005.

[32] Tsegaye, D., Belay, B., Aynalem, H. A. (2013): Linear body measurements as predictor of body weight in Hararghe Highland goats under farmers environment. Ethiopia. Global Veterinaria 11(5): 649-656.

[33] Tüzemen, N., Yanar, M. (2013): Buzağı yetiştirme teknikleri. - Atatürk University Agriculturel Science Printing House, Erzurum, Turkey, pp. 32-37.

[34] Tüzemen, N., Yanar, M., Akbulut, Ö., Uğur, F., Aydın, R.(1995): Prediction of body weights from body measurements in Holstein calves. - J. Agri Cooage of Atatürk University 26: 245-252.

[35] Yan, T., Mayne,C. S., Patterson, D. C., Agnew, R. E. (2009): Prediction of body weight and empty body composition using body size measurements in lactating dairy cows. Livestock Science 124: 233-241.

[36] Yanar, M., Tüzemen, N., Özhan, M., Aydin, R., Uğur, R. (1995): Prediction of body weights from body measurements in brown Swiss cattle. - Turk. J. Vet. Anim. Sci. 19: 357-360. 